\title{
Tracer tests, hydrochemical and microbiological investigations as a basis for groundwater protection in a remote tropical mountainous karst area, Vietnam
}

\author{
Vu Thi Minh Nguyet • Nico Goldscheider
}

\begin{abstract}
The Tam Duong karst area in NW Vietnam is among the poorest and remotest regions in the country. The local population largely depends on water from two main karst springs. Due to agricultural activity and untreated domestic wastewaters, the spring water is often microbiologically contaminated. In order to provide a scientific basis for groundwater protection in the area, different field methods have been applied including hydrogeological framework investigations, tracer tests, and hydrochemical and microbiological sampling and analyses. All methods had to be adapted to the conditions of a poor and remote area. These adaptations included, amongst other measures, the use of a portable microbiological water testing kit and the involvement of the local population in the sampling campaign. The tracer tests showed simple and direct connections between two important swallow holes and the two main springs, and made it possible to determine the linear groundwater flow velocities, which are extremely high (up to $875 \mathrm{~m} / \mathrm{h}$ ). The hydrochemical and microbiological data confirmed the strong impact of the streams sinking into the swallow holes on the spring water quality. Future groundwater source protection strategies should consequently focus on the reduction of polluting activities near the sinking streams and within their catchment areas.
\end{abstract}

Resumen El área kárstica Tam Duong al noroeste de Vietnam se encuentra entre las más pobres y remotas del

Received: 19 January 2006 / Accepted: 3 March 2006

Published online: 31 May 2006

(C) Springer-Verlag 2006

V. T. M. Nguyet

Department of Hydrology and Hydraulic Engineering,

Vrije Universiteit Brussel,

Pleinlaan 2, 1050 Brussels, Belgium

V. T. M. Nguyet

Research Institute of Geology and Mineral Resources (RIGMR), Ministry of Natural Resources and Environment,

Km 9 Nguyen Trai, Thanh Xuan, Hanoi, Vietnam

N. Goldscheider (

Centre of Hydrogeology (CHYN),

University of Neuchâtel,

Rue Emile-Argand 11 - CP 158 ,

2009 Neuchâtel, Switzerland

e-mail: nico.goldscheider@unine.ch país. La población local depende fuertemente del agua de dos manantiales kársticos principales. El agua del manantial se contamina frecuentemente con microbios por la extensa actividad agrícola y la descarga de aguas residuales domésticas sin ningún tratamiento. Para aportar bases científicas en la protección del agua subterránea del área se han aplicado diferentes métodos de campo incluyendo investigaciones del marco hidrogeológico, pruebas con trazadores, muestreo y análisis microbiológico e hidroquímico. Todos los métodos tuvieron que adaptarse a las condiciones pobres y remotas del área. Estas adaptaciones incluye, entre otras medidas, el uso de un kit manual de evaluación microbiológica del agua y el involucramiento de la población local en la campaña de muestreo. Las pruebas con trazadores mostraron una conexión directa y simple entre dos pozos someros importantes y los dos manantiales principales, haciendo posible determinar las velocidades lineares de flujo de agua subterránea las cuales fueron bastante altas (hasta $875 \mathrm{~m} / \mathrm{h}$ ). Los datos hidroquímicos y microbiológicos confirman el impacto fuerte de los arroyos hundidos en los pozos someros y en la calidad de agua del manantial. Las estrategias futuras de protección de agua subterránea deberían por lo tanto enfocarse en la reducción de actividades contaminantes cerca de los arroyos hundidos y dentro de sus áreas de drenaje.

Résumé La zone karstique de Tam Duong, au NO du Vietnam, fait partie des régions les plus pauvres et les plus reculées du pays. La population locale est largement dépendante de l'eau provenant de deux principales sources karstiques. En raison de la variété des activités agricoles et des eaux usées domestiques non traitées, l'eau de source subit souvent une contamination microbiologique. Afin de fournir une base scientifique pour la protection de l'eau souterraine dans cette zone, différentes méthodes de terrain ont été appliquées comprenant des investigations de base en hydrogéologie, des essais de traçage ainsi qu'un échantillonnage et des analyses hydrochimiques et microbiologiques. Toutes ces méthodes ont dû être adaptées aux conditions de cette zone pauvre et reculée. Ces adaptations ont inclus, parmi d'autres mesures, l'utilisation d'un kit portatif pour la microbiologie de l'eau et la participation de la population locale à la campagne d'échantillonnage. Les essais de traçage ont montré les connections simples et directes entre deux importantes pertes et les deux sources 


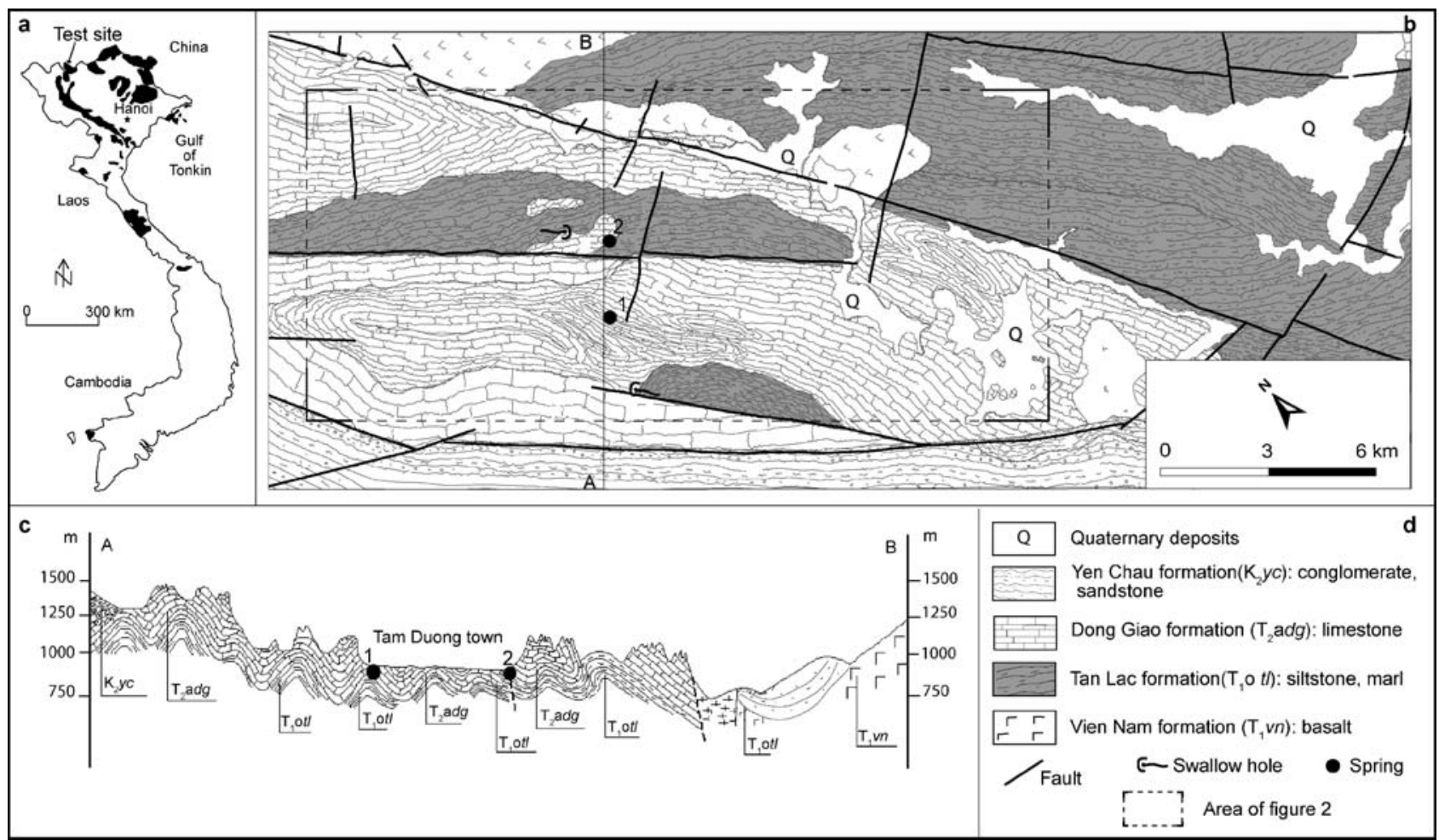

Fig. 1 a Map of Vietnam with carbonate (karst) areas in black and location of the test site. b Geological map of the Tam Duong area with location of the two most important swallow holes and springs; the dashed rectangle indicates the location of the maps in Figs. 2 and 3. c Geological cross-section with location of springs 1 and 2. d Legend of the map and section. Modified according to VIBEKAP (2003)

principales, et ils ont rendu possible la détermination des vitesses d'écoulement de l'eau souterraine, qui sont extrêmement élevées (jusqu'à $875 \mathrm{~m} / \mathrm{h}$ ). Les données hydrochimiques et microbiologiques ont confirmé le fort impact des cours d'eau plongeant dans les pertes sur la qualité de l'eau de source. En conséquence, les futures stratégies de protection de l'eau souterraine devraient se concentrer sur la réduction des activités polluantes à proximité des ruisseaux qui s'infiltrent et à l'intérieur du bassin versant.

Keywords Tropical karst · Microbial contamination . Tracer test · Groundwater protection

Socio-economic aspects

\section{Introduction}

Carbonate rocks cover about $215,000 \mathrm{~km}^{2}$ or $10 \%$ of the land surface of mainland Southeast Asia including some of the world's most spectacular tropical karst landscapes (Mouret 2004). Many of these karst areas hold important groundwater resources that are used as drinking water, for agriculture and industry. At the same time, karst aquifers are vulnerable to contamination resulting from human activity. Contaminants can easily reach the groundwater through thin soils or via swallow holes, and are rapidly transported over large distances in the conduit network (Vesper et al. 2001). Microbial pathogens are often the most problematic contaminants (Auckenthaler and Huggenberger 2003; Dussart-Baptista et al. 2003). Karst groundwater thus needs special protection. Tracer tests, hydrochemical and microbiological investigations are suitable methods for providing a scientific basis for the development of sustainable groundwater protection schemes (Bakalowicz 2005; Drew and Hötzl 1999).

The application of these techniques requires considerable financial, logistic and technical efforts including spring water monitoring and sampling, cooling and transport of the samples, and sophisticated analyses in microbiological and hydrochemical laboratories. In rich countries, these facilities are usually available. In developing countries and remote areas, however, such investigations are a challenge and require special methodological adaptations.

The Tam Duong karst area in NW Vietnam is among the poorest and remotest regions in the country (Fig. 1). It takes more than one day to get from Hanoi to the test site. The local population largely depends on water from karst springs, which is also used for irrigation, fishponds and a tea factory. Some years ago, Tam Duong used to be a small town with roughly 5,000 inhabitants. At the beginning of 2004, the provincial government decided to split up the existing province into two new provinces and proposed that Tam Duong should be the capital of the newly created Lai Chau province. Since then, many people have been moving to the town and there is construction work all around. At the end of 2004, about 
10,000 people were living in Tam Duong, and the town is continuing to grow. This means that both the freshwater demand and the land-use pressure are increasing.

The study presented in this paper is aimed at providing a scientific basis for groundwater protection in the Tam Duong area, and at better understanding the variability of microbial and hydrochemical water quality in tropical karst aquifer systems. The study was prepared within the framework of cooperation between the Research Institute of Geology and Mineral Resources (RIGMR) in Hanoi and the Centre for Hydrogeology at the University of Neuchâtel (CHYN) in Switzerland. It was the first detailed hydrogeological study in the region and included fieldwork in summer 2004 and subsequent laboratory work at the CHYN. The applied methods include hydrogeological mapping, hydrochemical and microbiological sampling and analyses, and a multi-tracer test. The methodology had to be adapted to the condition of a poor and remote tropical area. The local population helped with the sampling during the tracer test and thus contributed to the success of this study.

In recent years, several karst areas in Northern Vietnam have been studied within the framework of the Vietnamese-Belgian Karst Project (VIBEKAP), which includes speleological, geomorphological and hydrological investigations, remote sensing, geographic information systems (GIS), flooding prediction and other aspects and methods (Liu et al. 2004; Nguyet et al. 2004a; Tam et al. 2001, 2004, 2005; Hung et al. 2002). Previous activities in the Tam Duong area focused on speleological investigations, because Vietnam's deepest cave, the 600-m-deep Cong Nuoc cave, is located in the area (Dusar et al. 1994; BVSE 2002; VIBEKAP 2003).

\section{Test site description and framework investigations}

\section{Geographical and climatic overview}

The test site belongs to a large karst region in NW Vietnam that extends from the Chinese border towards the Gulf of Tonkin and covers about $8,200 \mathrm{~km}^{2}$ (Tuyet 1998). Tam Duong town is located in a NW-SE tending valley at an altitude of $800 \mathrm{~m}$. The steep conical hills at both sides of the valley, up to $1,400 \mathrm{~m}$ in altitude, also belong to the test site (Fig. 1).

The climate is tropical humid with an annual precipitation of 2,600 mm, most of which falls during the rainy season from May to October. The average annual air temperature is $20^{\circ} \mathrm{C}$ with a maximum in July to August and a minimum in December to January (weather station Tam Duong, 1996-2000, personal communication).

\section{Geological framework}

The mountain ranges in NW Vietnam were essentially formed during the Indian-Eurasian collision since the Eocene and can be considered as a prolongation of the
Himalayans. East of the main collision zone, crustal blocks escaped along strike-slip faults in an easterly direction. As the Indian plate progressed northwards, these faults often changed from left to right lateral movement; there was also temporal and spatial change from extension to compression (Tapponier et al. 1986). Northwest Vietnam is thus characterised by NW-SE tending faults, fold belts, and pull-apart basins. The faults cut the crust into slices that are difficult to connect due to important displacements. The Red River Fault, one of the major tectonic features in SE Asia, runs through NW Vietnam, adjacent to the Tam Duong area (Tri et al. 1977).

The studied area is formed of Triassic to Cretaceous sedimentary rocks. The Early Triassic Tan Lac formation is 300-600 m thick and predominantly consists of marl. The most prominent rocks are the 300-800-m-thick limestones of the Middle Triassic Dong Giao formation. The conglomerates and sandstones of the Cretaceous Yen Chau formation form the SW margin of the test site. To the NE, there is fault contact to the Vien Nam formation, mainly consisting of basalt. Shallow Quaternary gravel, sand and clay deposits locally cover the valleys. Structurally, the region is characterised by NW-SE tending folds. Most folds are entirely formed of Dong Giao limestone. The underlying marls are exposed along two large anticlines. Two main fault directions can be observed in the area: NW-SE and NE-SW, resulting from paleo- and neo-tectonic activity (My 1978; Thu and Ban 1996). There is important mineralisation in the sedimentary sequence, consisting of fluorite, barite and others. High contents of rare earth elements (REE) were found in these mineral deposits (Japanese Mining Project 2002).

\section{Karst development and basic hydrogeological characteristics}

The Dong Giao limestone is intensively karstified, and the test site represents a typical tropical tower karst landscape. The towers have the form of steep conical hills, which are often aligned and form peak clusters or isolated towers (Tuyet 1998). The 600-m-deep Cong Nuoc cave and many other caves are located in the area (Dusar et al. 1994; BVSE 2002). There are many dolines, some of which act as swallow holes. In most parts of the area, the karstified rocks are covered by shallow loamy soils and overgrown by vegetation. Epikarst development can be observed in road exposures and in quarries.

Hydrogeologically, the area is characterised by a thick karst aquifer (Dong Giao limestone) on top of a regional aquiclude (Tan Lac marl). Within the test site, the marls are exposed along the cores of two anticlines. Northeast of the main fault limiting the karst area, wide parts of the land surface consist of marls overlying basaltic rocks. These zones drain by surface runoff, while the limestone areas generally drain underground. Quaternary deposits are thin and restricted to small areas, and play no significant role for the regional hydrogeology. 


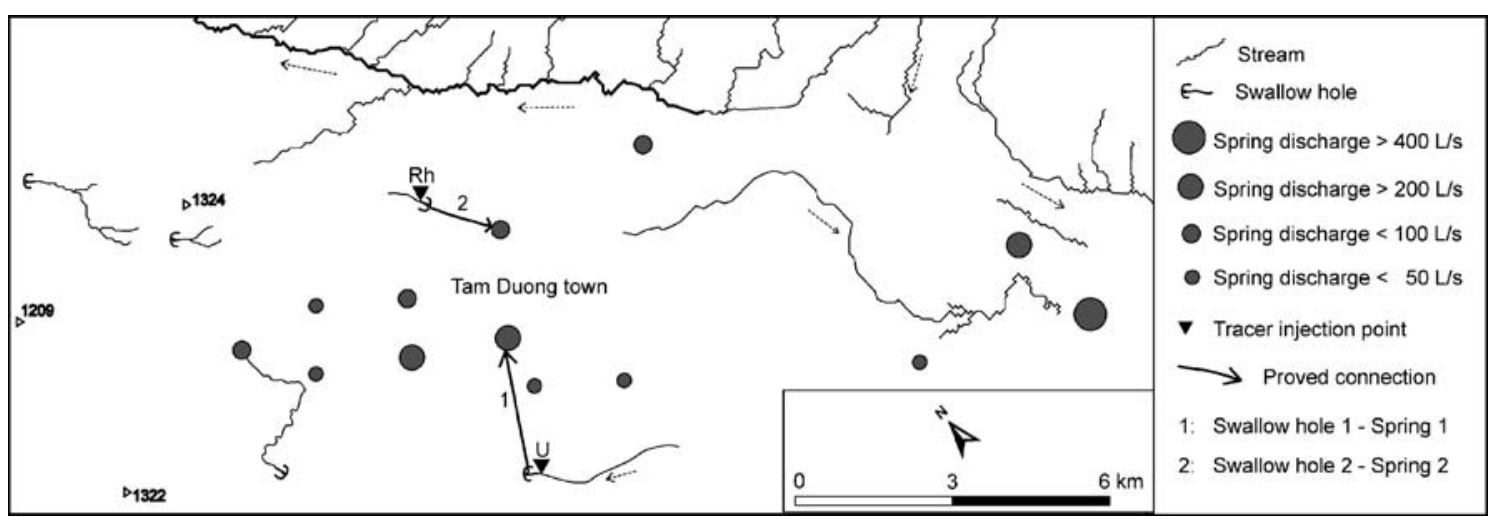

Fig. 2 Surface waters, springs and swallow holes in the study area. The tracer injection points and the underground connections proved by the tracer tests are also shown. For location of the map see Fig. 1b

\section{Surface waters, springs and swallow holes}

Most surface waters in the Tam Duong area flow over non-carbonate rocks (compare Figs. 1 and 2). The largest river developed on Tan Lac marl and Vien Nam basalt and flows parallel to the fault that forms the NE limit of the karst area. Surface streams often sink into swallow holes when they reach the karst area. These swallow holes are located at faults and/or near the contact between noncarbonate and karstified carbonate rocks. Most springs in the area discharge from the Dong Giao karst aquifer.

The study presented in this paper mainly focused on two karst springs (Dau Nguon Sin Ho and Nha May Che), which are simply named spring 1 and spring 2 . During the observation period in summer 2004, the water level at both springs was manually recorded on a daily basis. At spring 1, the discharge was measured at intervals using the salt-dilution method (Käss 1998). For practical reasons, such measurements were not possible at spring 2 . The discharge at this spring was thus estimated on the basis of channel width, water level and flow velocity. At the other springs in the area, the discharge was estimated and/or measured occasionally using different methods. The water level and discharge data presented in this paper only apply for the observation period; much higher and lower values are expected to occur during different hydrological conditions.

Spring 1 is situated at the SW margin of the Tam Duong Valley Basin at an altitude of $850 \mathrm{~m}$. It is used as a drinking water source for a part of the town. Geologically, it is located near the axis of an anticline, where the aquifer thickness is reduced. During the observation period, the discharge varied between about 200 and 400 L/s. Spring 2 is located at the same altitude on the other side of the valley, near a major fault and close to the contact of marl and limestone. The observed flow rate ranges between 50 and $100 \mathrm{~L} / \mathrm{s}$. Spring 2 is used as a drinking water source for the town and for a nearby tea factory.

Hydrogeological and speleological observations already indicated that the two springs are connected to two swallow holes, a hypothesis that was later confirmed by tracer tests (see below). Swallow hole 1 (Nung Nang) is located $3.0 \mathrm{~km} \mathrm{SW}$ of spring 1, and swallow hole 2 (Suoi Thau) is $1.75 \mathrm{~km} \mathrm{NW}$ of spring 2, both at an altitude of $1,000 \mathrm{~m}$. The catchment areas of the two sinking streams consist of marl, which is exposed in the cores of two anticlines. The two swallow holes are located near the

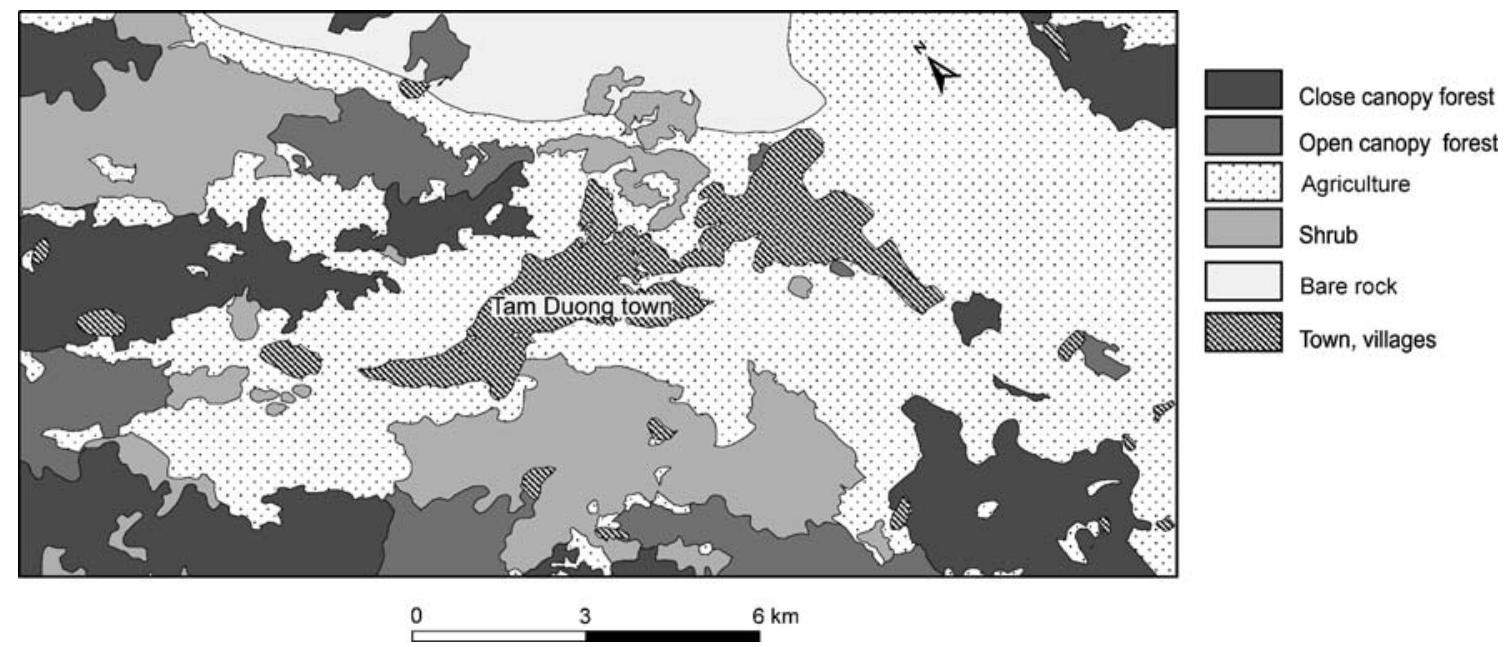

Fig. 3 Vegetation and land-use activities in the Tam Duong area. The map area is identical to Fig. 2 
stratigraphic contact between the marl and the overlying limestone. Due to their difficult accessibility, no flow measurements were carried out at the swallow holes. The estimated discharge of the sinking streams during the observation period was $70-120 \mathrm{~L} / \mathrm{s}$ at swallow hole 1 , and $30-60 \mathrm{~L} / \mathrm{s}$ at swallow hole 2.

\section{Land use activities and contamination hazards}

The land use and vegetation in the Tam Duong area can be classified into forest, agriculture, shrub, bare rock, town and villages (Fig. 3). Close and open canopy forest is preserved in the mountains and occupies approximately $26 \%$ of the area. Agricultural land uses predominate in the main valley of Tam Duong and in the higher valleys, occupying $43 \%$ of the area. Rice paddies and tea plantings are the most important regional agricultural products. There are also vegetable and fruit plantings, as well as cattle pasture and numerous fishponds that are often directly located at the springs. Settlements occupy $7 \%$ of the area. The town and some villages are situated in the central valley; other villages are located in the higher valleys.

The contamination hazards are concentrated in the agricultural and settlement areas. Possible contaminants include microbial pathogens, pesticides, and a wide range of organic and inorganic pollutants, such as gasoline. Pathogen contamination may originate from untreated domestic wastewaters, various agricultural activities and waste dumping. A hospital, a tea factory and two gasoline stations in the town are also possible sources of contamination.

\section{Multi-tracer test}

\section{Objectives and overview}

Tracer tests make it possible to obtain information on the underground flow pattern and the spring catchment areas, which is crucial for the development of groundwater source protection strategies. A multi-tracer test was carried out in the test site in order to:

- Confirm or refute the assumed connection between swallow hole 1 and spring 1 , and between swallow hole 2 and spring 2 (Fig. 2)

- Quantify the proportion of water from the swallow holes that resurges at the springs

- Check if there is connection between the swallow holes and other springs in the area

- Determine the linear groundwater flow velocities and characterise contaminant transport in the karst conduit network

The two swallow holes were selected as injection points, while the karst springs were sampled to observe a possible tracer arrival. The common methodology of groundwater tracing had to be adapted to the conditions of a poor and remote tropical karst area.
Adaptation of the method and experimental design Some fluorescent dyes are among the best groundwater tracers. Due to their extremely low detection limits (e.g. uranine: $0.005 \mu \mathrm{g} / \mathrm{L}$ ), only small injection quantities are required (Käss 1998). This makes it possible to use fluorescent dyes even in remote and mountainous areas with limited transport facilities. For the tracer tests in the Tam Duong area, separate containers containing $500 \mathrm{~g}$ of uranine and $500 \mathrm{~g}$ of rhodamine B were prepared. The containers with the dry powder were carried to the injection points and dissolved on site in buckets full of water. On the 9 September 2004, uranine was injected into swallow hole 1 and rhodamine B into swallow hole 2 .

There are three different monitoring strategies for fluorescent dyes: continuous measurement using a field fluorimeter, discrete water sampling, which can be done with an automatic sampler or manually, and integrative sampling with charcoal bags. The installation of field fluorimeters and automatic samplers was not considered in the test site, as these expensive instruments were not available in the region. Käss (1998) recommends 50-ml brown glass bottles for manual water sampling; the samples must be stored in the dark as most dyes decay when exposed to daylight. However, a large number of water filled glass bottles are heavy and expensive to transport. 'Lightproof' $13 \mathrm{ml}$ plastic test tubes were thus used for sampling. A total of 96 water samples were taken during the tracer test, which means only about $1.3 \mathrm{~kg}$ of weight. Charcoal bags are also lightweight and stable when dry.

At the two main springs, water samples were taken at short time-intervals, ranging from $30 \mathrm{~min}$ to several hours. Charcoal bags were installed at ten other springs. Local people and the local army division did the sampling, perfectly following the instructions. The samples were transported to the CHYN laboratory and analysed with a spectrofluorimeter (PERKIN ELMER LS 50 B).

\section{Results}

The uranine that was injected into swallow hole 1 arrived only at spring 1 , and the rhodamine B that was injected into swallow hole 2 reappeared only at spring 2 (Fig. 2). No trace of the two dyes was detected at any other sampling point in the area.

Uranine first arrived $41.5 \mathrm{~h}$ after injection and reached a maximum of $21.3 \mu \mathrm{g} / \mathrm{L}$ after $53.5 \mathrm{~h}$ (Fig. 4a; please note: all given time values are hours after injection). The distance between the swallow hole and the spring is $3,000 \mathrm{~m}$, and so the maximum linear flow velocity is $72 \mathrm{~m} / \mathrm{h}$ while the dominant flow velocity is $56 \mathrm{~m} / \mathrm{h}$. After roughly $200 \mathrm{~h}$, the tracer breakthrough was completed, i.e. the concentration dropped below detection limit.

Rhodamine B first arrived at spring 2 between 2.0 and $2.5 \mathrm{~h}$ after the injection (Fig. 4b). As the sampling interval was $30 \mathrm{~min}$, the time of first arrival cannot be determined more precisely. The highest concentration, $1,242 \mu \mathrm{g} / \mathrm{L}$, was measured in a water sample taken after $3.0 \mathrm{~h}$; the maximum must thus have occurred between 2.5 and $3.0 \mathrm{~h}$. 

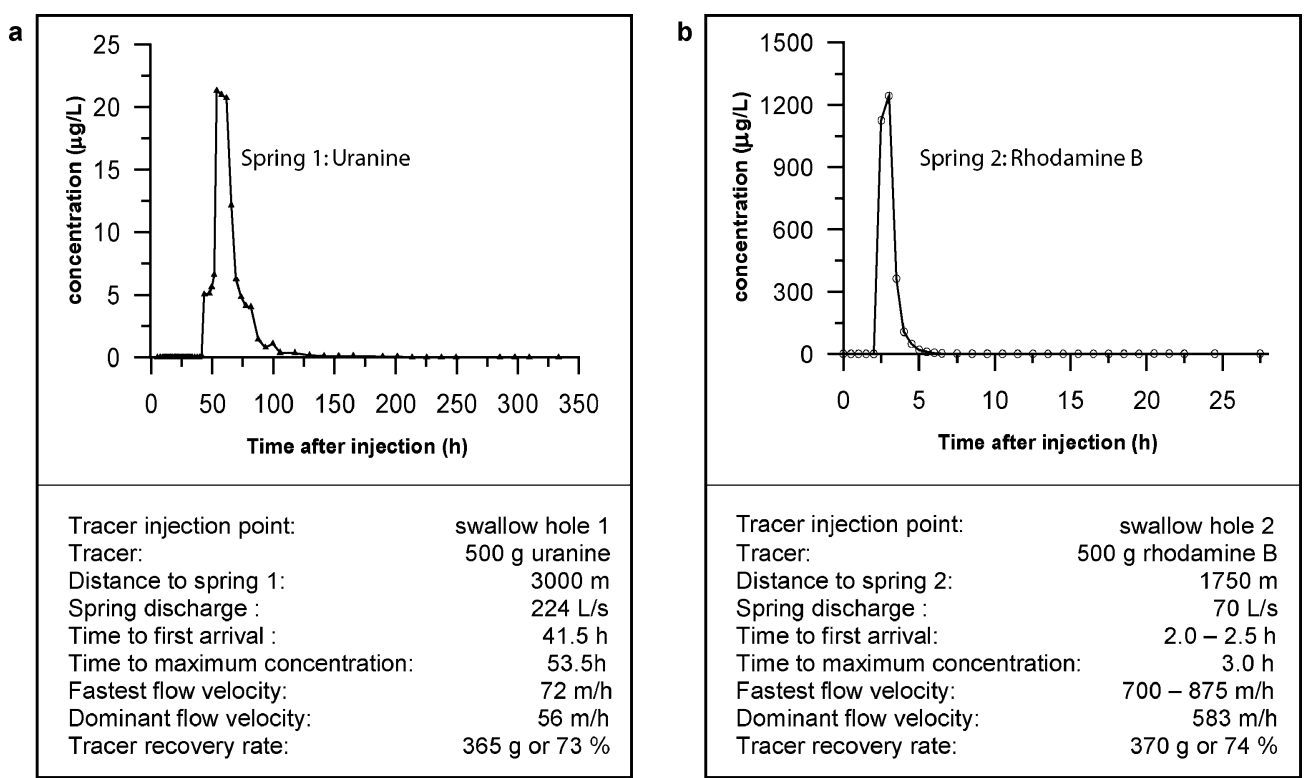

Fig. 4 Results of the multi-tracer test in the Tam Duong area: a spring 1 with uranine, $\mathbf{b}$ spring 2 with rhodamine B

The distance between the swallow hole and the spring is $1,750 \mathrm{~m}$. The maximum linear flow velocity thus ranges between 700 and $875 \mathrm{~m} / \mathrm{h}$, while the dominant linear velocity ranges between 583 and $700 \mathrm{~m} / \mathrm{h}$. After $10.5 \mathrm{~h}$, the concentration dropped below the detection limit.

The precise calculation of the tracer recovery requires continuous discharge data. As such data are not available, single flow measurements or estimations had to be used (see above). The approximate tracer recovery was then calculated by multiplying the discharge value with the area below the corresponding tracer breakthrough curve. At spring 1, a discharge of $224 \mathrm{~L} / \mathrm{s}$ was measured on 10 September 2004. The calculated uranine recovery at spring 1 is $365 \mathrm{~g}$ or $73 \%$. The estimated discharge at spring 2 during the tracer breakthrough was about $70 \mathrm{~L} / \mathrm{s}$, and the calculated tracer recovery for rhodamine $\mathrm{B}$ is $370 \mathrm{~g}$ or $74 \%$.

For questions of groundwater protection, it is also interesting to estimate the percentage of spring discharge $\left(P_{Q}\right)$ that can be attributed to the sinking stream flow. Assuming conservative tracer behaviour, this can be done using the following formula:

$P_{Q}=R \cdot \frac{Q_{s w h}}{Q_{s p}}$

where $R$ is the tracer recovery rate (\%), $Q_{s w h}$ is the discharge at the swallow hole where the tracer has been injected $(\mathrm{L} / \mathrm{s})$, and $Q_{s p}$ is the discharge at the spring $(\mathrm{L} / \mathrm{s})$. During the tracer test, the estimated flow rates were $90 \mathrm{~L} / \mathrm{s}$ at swallow hole 1 and $40 \mathrm{~L} / \mathrm{s}$ at swallow hole 2 . This means that $29 \%$ of the discharge of spring 1 can be attributed to swallow hole 1 , while approximately $42 \%$ of the discharge of spring 2 originates from swallow hole 2 . Although these calculations are based on estimated discharge values, it is possible to state that a significant proportion of the spring water originates from the corresponding sinking stream.

\section{Hydrochemistry}

\section{Objectives and overview}

The WHO (2004) guidelines for drinking-water quality defines limits for a variety of water constituents, including dissolved inorganic compounds like nitrate $(50 \mathrm{mg} / \mathrm{L})$. The research programme in the Tam Duong area thus included hydrochemical analyses that aimed at characterising spring water quality and its spatial and temporal variability. Another objective was to obtain information on geochemical aquifer properties, groundwater residence times and mixing processes between different water types, in other words, to use the chemical compounds as natural tracers (Scanlon 1990; Vaute et al. 1997).

\section{Adaptation of the method, sampling strategy and analyses}

Standard hydrochemical investigations for dissolved inorganic compounds usually comprise measurements in the field, water sampling and laboratory analyses. Field measurements in the test site included $\mathrm{pH}$, temperature (T) and specific electrical conductivity (EC). Turbidity was measured visually using a simple turbidity tube. The monitoring of spring discharge and water level has been described above in the section on surface waters, springs and swallow holes.

Inorganic cations are usually analysed in filtered and acidified $100 \mathrm{ml}$ water samples; filtered samples of $500 \mathrm{ml}$ are often used for anions. Bicarbonate $\left(\mathrm{HCO}_{3}{ }^{-}\right)$is the dominant anion in many karst waters (Dreybrodt 2000). Inorganic carbon species, i.e. $\mathrm{HCO}_{3}{ }^{-}, \mathrm{CO}_{3}{ }^{2-}$ and $\mathrm{CO}_{2}$, are 
a

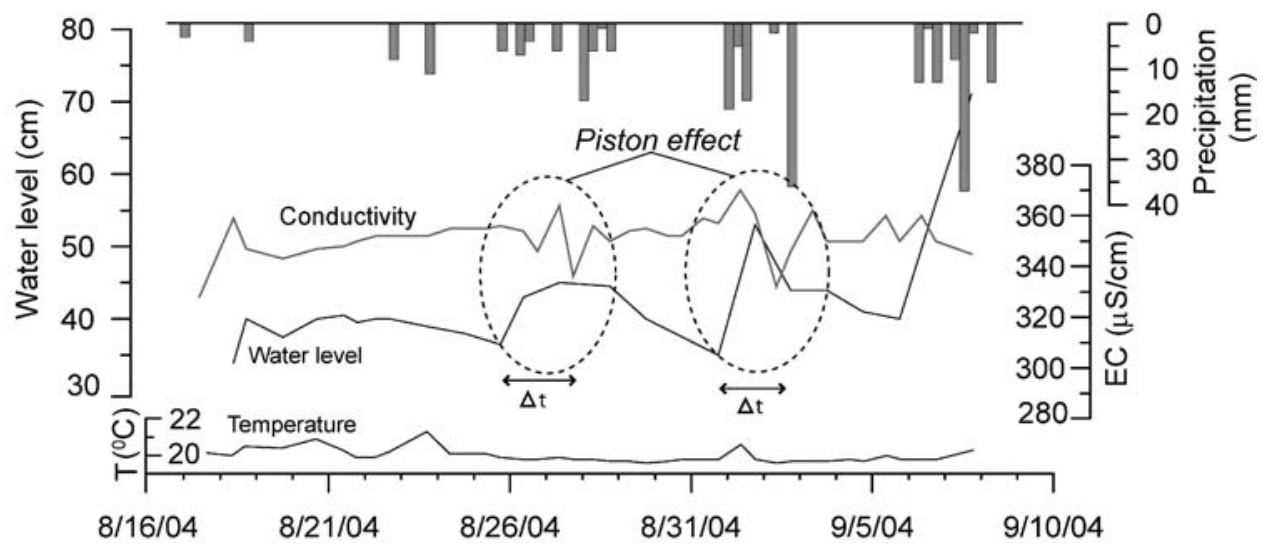

b
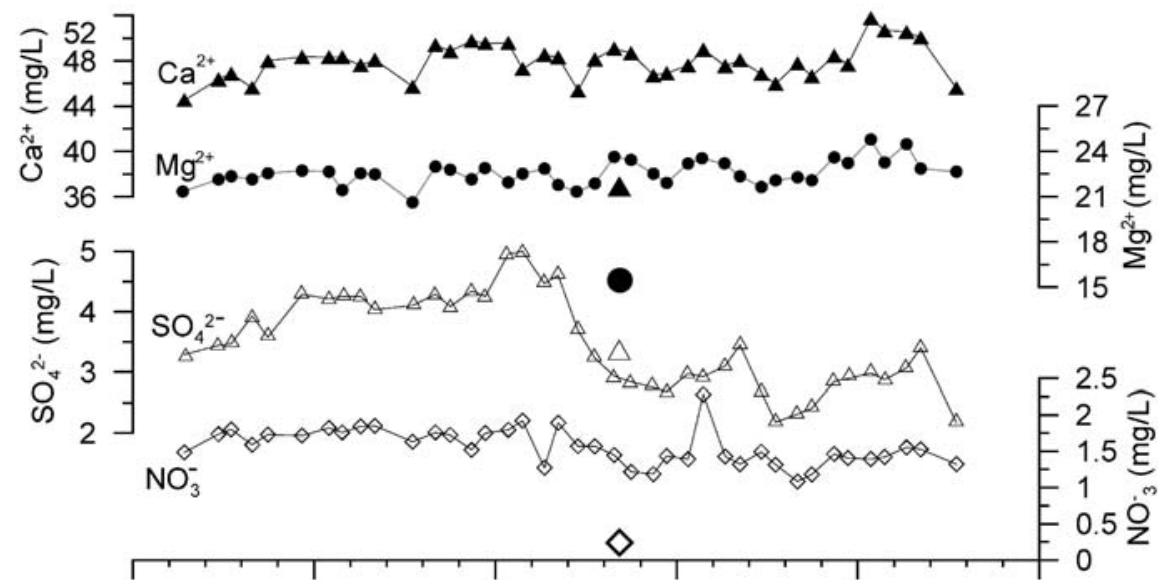

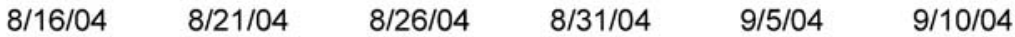

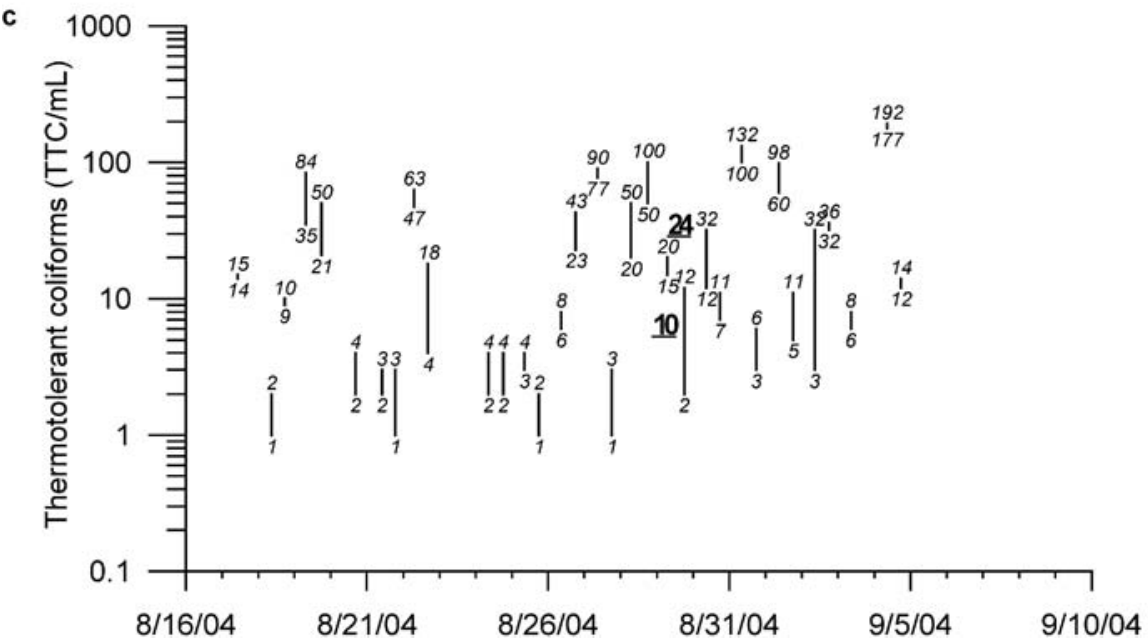

Fig. 5 a Precipitation in the Tam Duong area and observed variations of water level, electrical conductdivity (EC), temperature, $\mathbf{b}$ selected hydrochemical parameters, and $\mathbf{c}$ thermotolerant coliforms (TTC) at spring 1 . The large symbols (circle, triangles, diamond) in $\mathbf{b}$ and the bold underlined numbers in $\mathbf{c}$ represent the hydrochemical and microbial parameters measured in a water sample taken at swallow hole 1 on 29 August 2004

generally analysed by means of titration with $\mathrm{HCl}$ and $\mathrm{NaOH}$ respectively. This can be done directly in the field or in large (e.g. $500 \mathrm{ml}$ ) untreated water samples that must be stored cool and analysed as soon as possible (Dean 1995; Drever 1997).

At the test site, it was not practicable to collect a large number of heavy water samples, store them cool and transport them to a laboratory. Therefore, $13 \mathrm{ml}$ plastic test tubes were used for sampling. The samples for the cations were filtered and acidified; the samples for the anions were only filtered. In the CHYN laboratory, the samples were analysed for $\mathrm{Ca}^{2+}, \mathrm{Mg}^{2+}, \mathrm{Na}^{+}, \mathrm{K}^{+}, \mathrm{NH}_{4}^{+}, \mathrm{SO}_{4}{ }^{2-}, \mathrm{Cl}^{-}, \mathrm{NO}_{3}{ }^{-}$, $\mathrm{NO}_{2}^{-}$and $\mathrm{F}^{-}$using ion chromatograph (DIONEX DX120). Inorganic carbonate species were not measured, as 


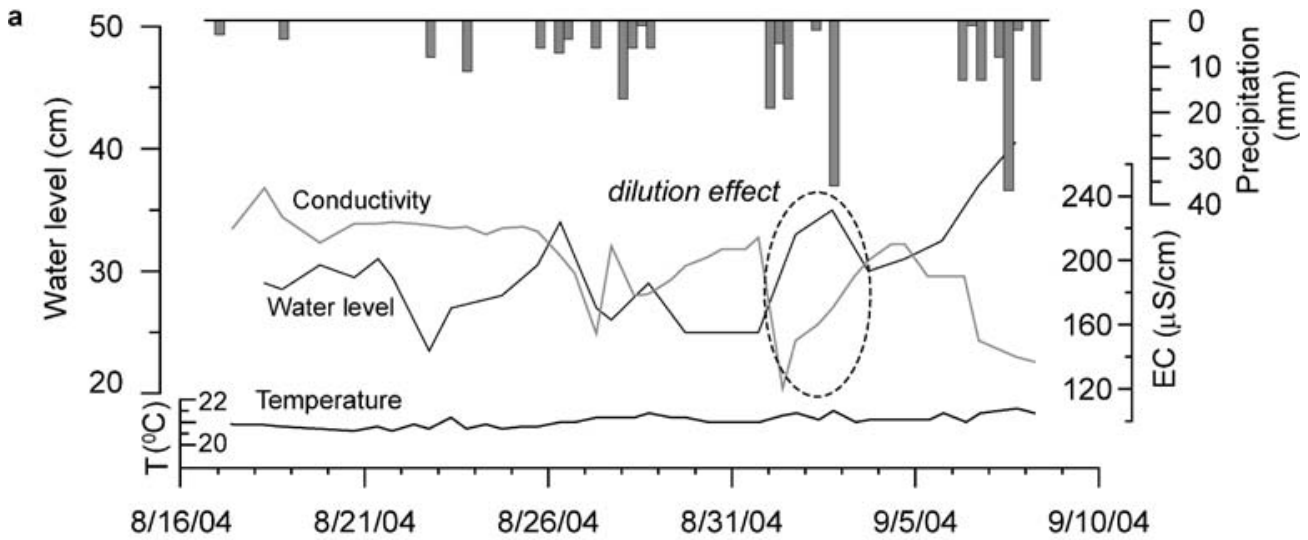

b
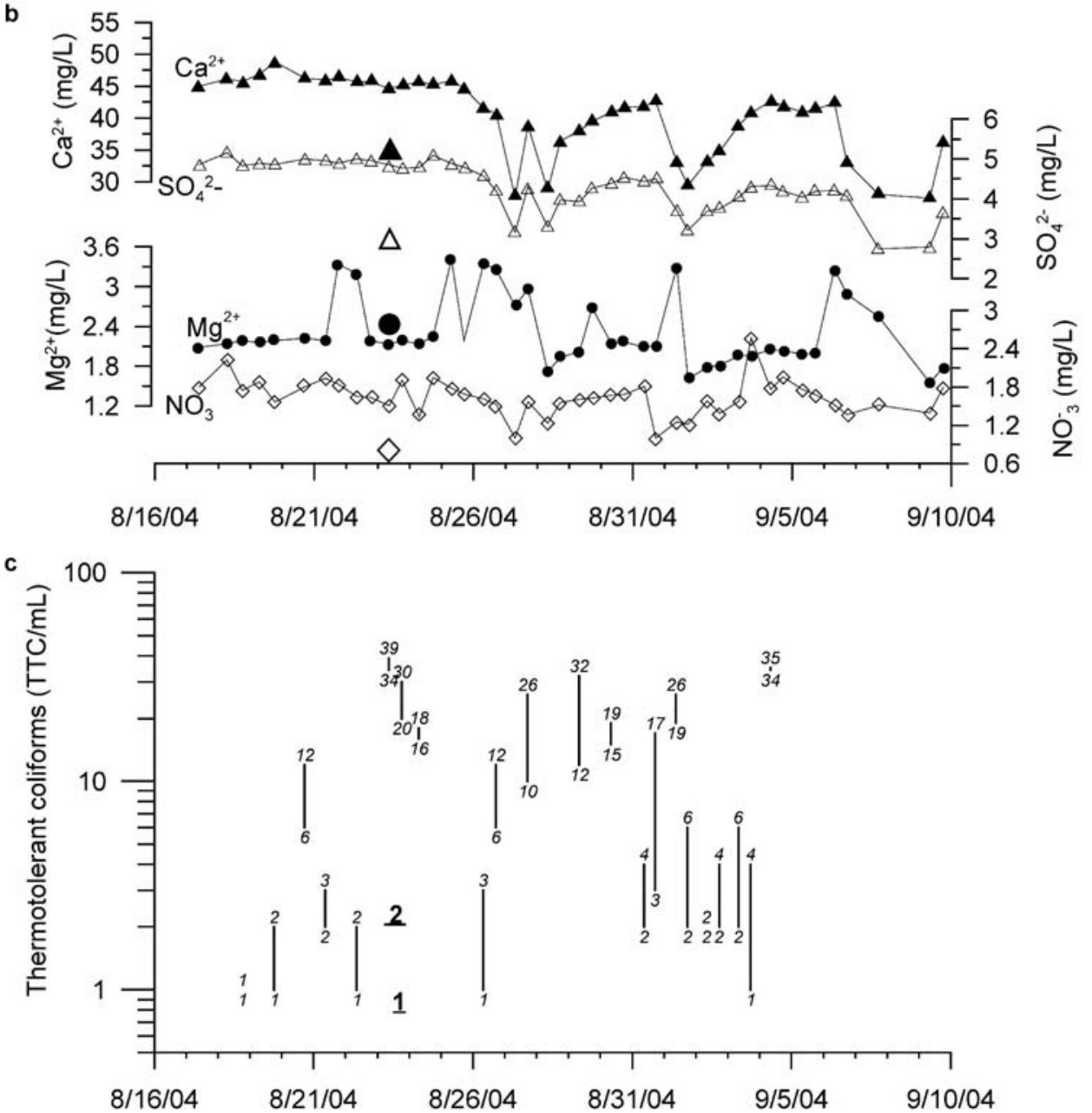

Fig. 6 a Variations of water level, electrical conductivity (EC), temperature, b hydrochemical and $\mathbf{c}$ microbiological parameters at spring 2. The large symbols (circle, triangles, diamond) in $\mathbf{b}$ and bold underlined numbers in $\mathbf{c}$ represent a sample taken at swallow hole 2 on 23 August 2004

this would have required additional field equipment or larger sample volumes. $\mathrm{HCO}_{3}{ }^{-}$was thus calculated on the basis of the ion balance, $\mathrm{CO}_{3}{ }^{2-}$ is not relevant at $\mathrm{pH}<8.2$, and $\mathrm{CO}_{2}$ does not contribute to the ion balance.

Karst spring chemographs often show strong and rapid reactions on hydrologic events and contaminant release (Panno et al. 2001; Ryan and Meiman 1996). In most cases, it is thus insufficient to analyse only a single water sample. On the other hand, it is not practicable to sample in short time-intervals at all springs. The temporal-spatial sampling strategy thus needs to be adapted to the local conditions, the goals of the study, and the budget.

As described above, the study in the Tam Duong area focused on the two most important springs. During the observation period (17 August 2004-9 September 2004), two samples per day were taken at these springs. Field 
data (temperature, $\mathrm{EC}, \mathrm{pH}$, water level) were collected at each sampling event; turbidity was measured occasionally. Several rainfall events occurred during the observation period, and so it was possible to record the variability of the different parameters. Only one sample was taken at 15 other sites in the area, including the two main swallow holes, in order to get an overview of the spatial distribution of the hydrochemical characteristics.

\section{Results}

The hydrographs and chemographs of spring 1 (Fig. 5) and spring 2 (Fig. 6) show many similarities but also significant differences. At both springs, $\mathrm{Ca}^{2+}$ is the dominant cation and $\mathrm{HCO}_{3}{ }^{-}$(calculated from the ion balance; not shown) is the dominant anion. Other important cations in the order of decreasing concentration are $\mathrm{Mg}^{2+}, \mathrm{Na}^{+}$and $\mathrm{K}^{+}$, while $\mathrm{SO}_{4}{ }^{2-}, \mathrm{NO}_{3}{ }^{-}$and $\mathrm{Cl}^{-}$are the most relevant anions. Nitrate concentrations at both springs range between 1.0 and $2.6 \mathrm{mg} / \mathrm{L}$, far below the WHO standard of $50 \mathrm{mg} / \mathrm{L}$. Ammonium and nitrite are below the detection limits $(0.01 \mathrm{mg} / \mathrm{L})$ in almost all samples. Fluoride concentrations of up to $0.8 \mathrm{mg} / \mathrm{L}$ were measured. This is below the WHO standard of $1.5 \mathrm{mg} / \mathrm{L}$ but higher than typical values for groundwater from limestone aquifers (Drever 1997; Saxena and Ahmed 2003). The elevated fluoride concentrations can be explained by the presence of hydrothermal fluorite mineralisation in the area, often visible as violet crystals in the limestone.

The main difference between the two springs is the $\mathrm{Mg}^{2+}$ content. At spring $1, \mathrm{Mg}^{2+}$ concentrations range between 21.3 and $24.8 \mathrm{mg} / \mathrm{L}$, while only 1.6 to $3.4 \mathrm{mg} / \mathrm{L}$ were found in spring 2. Magnesium was also analysed in samples from the two swallow holes. In swallow hole 1, $15.4 \mathrm{mg} / \mathrm{L} \mathrm{Mg}^{2+}$ was measured, while only $2.4 \mathrm{mg} / \mathrm{L}$ was found in swallow hole 2 . The different concentrations at the springs can thus partly be attributed to the geochemical characteristics of the sinking stream catchments.

The two springs show a high temporal variability of all hydrologic, physical and chemical parameters. However, spring 2 shows a higher variability than spring 1, this means it reacts more rapidly and strongly on hydrologic events.

After heavy rainfall events, the discharge (measured as water level) at spring 1 increases, and EC increases almost simultaneously. This observation indicates the arrival of higher mineralised water from deeper zones of the aquifer due to increasing hydraulic pressure in the aquifer. About $40 \mathrm{~h}$ after this first increase of spring discharge, EC decreases significantly, which indicates the arrival of freshly infiltrated water from swallow hole 1. This type of behaviour is known as a piston effect (Ford and Williams 1989). The time lag between the precipitation event and the arrival of fresh water at the spring roughly corresponds to the tracer travel time from the swallow hole to the spring 1 (see above). Spring 2 reacts differently. Discharge increases almost immediately after a precipitation event while EC decreases. This dilution effect indicates the rapid arrival of rainwater at the spring.

Hydrochemical data from the other sampling sites are similar to those found at the two main springs. Slightly elevated nitrate concentrations were found at two springs that are close to rice paddies, 11.4 and $13.1 \mathrm{mg} / \mathrm{L}$, which is still below the limits defined by the WHO (2004).

\section{Microbiology}

\section{Objectives and overview}

Waterborne microbial infections pose a major threat to human health, mainly in developing countries (WHO 2004). However, most microorganisms in groundwater are harmless, and some play important roles in natural attenuation processes (Chapell 2001; Goldscheider et al. 2006; Smets et al. 2002). Pathogenic microorganisms most often originate from faecal contamination at or near the land surface. The presence of faecal bacteria in the water thus indicates the possible presence of microbial pathogens including bacteria, protozoans and viruses (Auckenthaler and Huggenberger 2003). Karst aquifers are particularly vulnerable to microbial contamination. In rural karst areas, this type of contamination is often the only water quality problem, while chemical contaminants are not evident (Boyer and Pasquarell 1999; Mahler et al. 2000; Pasquarell and Boyer 1995).

One of the main goals of the study in the Tam Duong area was to characterise the microbial spring water quality and to better understand the occurrence, transport and variability of microorganisms in tropical karst aquifer systems. Therefore, microbiological water analyses played a crucial role within the framework of this study. In karst spring waters, microbiological parameters are often extremely variable. In some cases, it was possible to establish correlation between microbiological parameters on one hand and hydrologic, physical and hydrochemical parameters on the other hand, for example precipitation, discharge, turbidity, DOC or nitrate (Auckenthaler et al. 2002; Pronk et al. 2006). Therefore, the study in the Tam Duong area also aimed at identifying parameters that could be used as indicators for the presence of microbial pathogens.

\section{Adaptation and application of the method}

Microbiological analyses usually require sterile water sampling, cooling of the samples, and rapid transport to a microbiological laboratory (Hurst et al. 2002). In a poor, tropical and remote area like Tam Duong, such procedure is nearly impossible. Therefore, the portable water testing kit OXFAM-DELAGUA (2004) was used. This equipment is designed to test for the critical parameters specified in the WHO guidelines (2004).

The testing kit can be used to analyse for different types of indicator bacteria by varying the cultivation conditions, i.e. the growth medium, incubation temper- 
ature and time. In the Tam Duong area, the samples were analysed for thermotolerant coliforms (TTC), as these are considered to be of high sanitary significance (WHO 2004). According to the WHO standards, thermotolerant coliforms must be absent in a 100-ml water sample.

The first step of the analysis is to pass a defined water volume through a sterile filter, which is then placed on a paper pad soaked in liquid growth medium. After 16-18 h of incubation at $44^{\circ} \mathrm{C}$, the colonies are counted. The result is given in TTC/ml. Sampling volumes between 1 and $100 \mathrm{ml}$ can be chosen dependent on the bacteria content. In order to minimise counting errors, each water sample was analysed at least in two different volumes. The sampling strategy for the microbiological investigations was the same as described for the hydrochemical sampling: Two samples per day were taken at the two main springs; only one sample was taken at the two swallow holes and the other springs in the area.

\section{Results}

The results of the microbiological investigations at the two main springs are presented in Figs. 5 and 6, together with the hydrological and hydrochemical data. As mentioned above, each sample was analysed in two different sampling volumes; the results from both analyses are presented in order to illustrate the reproducibility of the method. All samples taken at springs 1 and 2 contained thermotolerant coliforms and thus exceed the WHO standards.

The contents of thermotolerant coliform bacteria at the two springs show sudden and strong temporal variations. At spring 1, between 1 and $192 \mathrm{TTC} / \mathrm{ml}$ were counted; 1$39 \mathrm{TTC} / \mathrm{ml}$ were detected in samples from spring 2. It was not possible to establish a correlation between the bacteria contents and any hydrologic, physical or hydrochemical parameters. It is thus impossible to predict the bacteria content based on monitoring these parameters. The bacteria content in a sample from swallow hole 1 was similar to the content measured at spring 1 on the same day, and the bacteria content in a sample from swallow hole 2 was similar to the content measured at spring 2 (bold underlined data in Figs. 5 and 6). This observation is consistent with the tracer test results that proved direct connection between the swallow holes and the springs. It is also consistent with the hydrochemical data that show a high degree of similarity between the swallow holes and the springs.

\section{Discussion and conclusions}

\section{Applicability of the methodology}

Carrying out hydrogeological research in a remote and poor tropical karst area required several methodological adaptations. Besides basic hydrological and geological observations, the techniques applied in the test site included a multi-tracer test, hydrochemical investigations and microbiological analyses. The main adaptations that were done for the tracer tests consisted of the use of very small and 'lightproof' test tubes for water sampling, the installation of charcoal bags at sampling sites of secondary importance, and the participation of local people to the sampling campaign. Hydrochemical investigations included the use of simple field instruments, and water sampling in small plastic test tubes. All inorganic anions and cations can be analysed in such small volumes, except for bicarbonate. The concentration of this anion was thus calculated on the basis of the ion balance. As a consequence, it was not possible to use the ion balance to control the precision of the chemical analyses. A portable water testing kit was used for the microbiological monitoring. This kit allows total thermotolerant coliforms (TTC) to be analysed. These bacteria are considered as indicators for the presence of pathogenic microorganisms of faecal origin (WHO 2004). However, some coliforms (Enterobacter, Klebsiella, Citrobacter) are of non-faecal origin and may occur in 'non-contaminated' water (Payment et al. 2003).

The combination of tracer tests, hydrochemical and microbiological techniques made it possible to better understand the karst aquifer system, and to characterise the dynamics and interaction of hydrologic, hydrochemical and microbiological parameters. The study also provided a basis for the development of future groundwater protection schemes. The proposed methodology is also applicable in other poor, remote and tropical areas.

\section{Hydrogeological characteristics of the karst aquifer system}

The tracer tests proved direct, rapid and simple connection between swallow hole 1 and spring 1 (karst flow system 1), and between swallow hole 2 and spring 2 (flow system 2 ). The high tracer recovery rates, at least about $70 \%$, suggest that most of the water sinking into the swallow holes reappears at the springs. The other way round, an important proportion of the spring water originates from the swallow holes, at least about one third, although this quantity is partly based on estimated discharge values. Hydrochemical data confirm the impact of the swallow holes on the springs. Allogenic point recharge thus predominates in the Tam Duong area, while autogenic diffuse recharge through the soil and epikarst seems to be less important. Such straightforward connections between a large swallow hole and a spring are rather an exceptional case. In many other karst systems, there are more complex connections between several swallow holes and springs, and autogenic recharge is often more important (Bakalowicz 2005; Ford and Williams 1989).

Linear groundwater flow velocities in karst aquifers determined by tracer tests often range between 10 and $300 \mathrm{~m} / \mathrm{h}$ and rarely exceed $700 \mathrm{~m} / \mathrm{h}$ (Ford and Williams 1989, Käss 1998). To the best of the authors' knowledge, the highest velocity documented in the literature is $1,450 \mathrm{~m} / \mathrm{h}$ (Aley 1975). The maximum flow velocity of 700 to $875 \mathrm{~m} / \mathrm{h}$ that was observed in flow system 2 is thus extremely high. The velocities in flow system 1 are within 


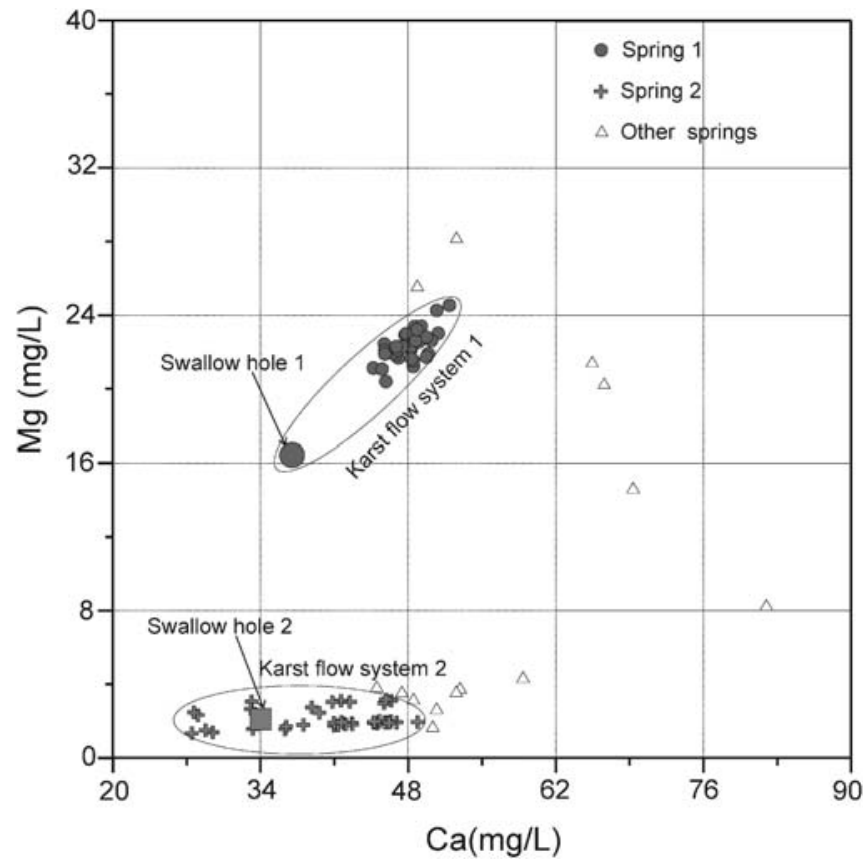

Fig. 7 Graphical presentation of the $\mathrm{Mg}^{2+}$ and $\mathrm{Ca}^{2+}$ concentrations measured in all water samples from the Tam Duong area. The samples from spring 1 form a group that is clearly separated from spring 2 . There is a close hydrochemical relation between the springs and the swallow holes to which they are connected

the typical range for karst aquifers. The high velocities and tracer recovery rates suggest that underground flow mainly occurs in conduits. Speleological and geomorphological observations further confirm the existence of a linear karst conduit with a cave stream connecting swallow hole and spring 2 .

Both paleo-tectonic and neo-tectonic fault directions control the underground flow pattern in the Tam Duong area. The straight karst conduit that connects swallow hole 2 to spring 2 runs parallel to the NW-SE faults (paleotectonics). Flow system 1 mainly follows SW-NE striking faults (neo-tectonics) and crosses several folds. Due to the high thickness of the karstified carbonate sequence, the degree of stratigraphic flow control is limited. Therefore, the influence of fold structures on the flow paths is also limited. In karst systems with a high degree of stratigraphic flow control, e.g. a thin karst aquifer between thick aquicludes, folds often have an important influence on the underground flow paths (Goldscheider 2005a).

\section{Dynamics and interaction of the hydrochemical and microbiological parameters}

Both hydrochemical and microbiological parameters at the two main springs show a high degree of variability, which is typical for karst springs (Ford and Williams 1989).

The hydro- and chemographs of the two springs react differently on rainfall events. Spring 2 shows a pure dilution effect, i.e. freshly infiltrated rainwater arrives rapidly at the spring and dilutes the water in the aquifer. The piston effect can be observed at spring 1. During high-flow events, increasing hydraulic pressure in the aquifer mobilises higher mineralised groundwater. The freshly infiltrated rainwater arrives with roughly 40-h delay, which corresponds to the transit time between swallow hole 1 and spring 1 proved by the tracer test.

Hydrochemically, water from swallow hole 1 and spring 1 can clearly be differentiated from water from swallow hole 2 and spring 2. Water from the former contains significantly more magnesium, which indicates the presence of dolomites in the catchment area of swallow hole and spring 1 . In the $\mathrm{Mg}^{2+} / \mathrm{Ca}^{2+}$ plot, water samples flow system 1 form a cluster, which is clearly separated from the cluster representing flow system 2 (Fig. 7). The plot also shows that the $\mathrm{Mg}^{2+}$ and $\mathrm{Ca}^{2+}$ concentrations are increasing during the underground passage from the swallow holes to the springs, which can be explained by additional mineral dissolution and mixing processes within the aquifer.

The contents of thermotolerant coliforms at spring 1 varied between 1 and $192 \mathrm{TTC} / \mathrm{ml}$, while 1-39 TTC/ml were measured at spring 2 . The bacteria levels often showed sudden and strong variations, e.g. $1-2 \mathrm{TTC} / \mathrm{ml}$ in one sample and 34-39 TTC in the following sample that was taken only $12 \mathrm{~h}$ later. The bacteria levels do not correlate with any other parameters and thus appear to be largely unpredictable. On the basis of the existing data, it is thus not possible to use hydrological, physical or chemical data as indicators for microbial groundwater quality, as it can be done in other karst systems (Pronk et al. 2006).

\section{Consequences for groundwater protection}

In all water samples from the two main springs, the concentrations of nitrate, fluoride and all other inorganic 
ions are clearly below the limits defined by the WHO (2004). The hydrochemical water quality thus seems to be excellent. The samples were not analysed for organic contaminants, like pesticides, which might be present in an agricultural area (Currens 2002; Young 1983). In contrast, all water samples contain thermotolerant coliforms, which should not be present in drinking water according to the WHO standards. The microbiological spring water quality is thus insufficient and measures should be taken to improve the quality. These measures should include the delineation of groundwater source protection zones and the implementation of an appropriate drinking water treatment, i.e. filtration and sterilisation.

Microbiological contamination of the spring water probably results from agricultural activities and untreated domestic wastewaters. The hydrogeological study clearly demonstrated that surface waters sinking into the two swallow holes rapidly arrive at the two springs. Most of the sinking stream water reappears at the springs, and an important percentage of the spring water in turn originates from the swallow holes. Protection zones and adaptations in land use practices around the two swallow holes and sinking streams, and within their hydrologic catchments, could thus help to reduce microbiological contamination of the two main springs.

Groundwater vulnerability, hazard and risk maps are important elements of groundwater protection schemes (Goldscheider 2005b; Veselic 2003). The European COST Action 620 proposed an approach to vulnerability, hazard and risk mapping for the protection of carbonate (karst) aquifers (Zwahlen 2004). This approach was developed by European scientists having in mind the hydrogeological and economic conditions in their countries. The authors of this paper also work on the adaptation of the European approach to the conditions of poor and remote areas, where little data are available (Nguyet et al. 2004b; Nguyet and Goldscheider in press). The simplified methodology will consist of a method of vulnerability mapping that takes into account the overlying layers $(\mathrm{O})$ and the concentration of flow $(C)$ that occur in the catchment areas of sinking streams. As illustrated above, the $C$ factor is particularly relevant for the Tam Duong test site. The land use map (Fig. 3) is the starting point for a simplified hazard assessment. A risk map can be obtained by overlying the vulnerability map and the hazard assessment. The vulnerability map can be used as a basis to delineate groundwater protection zones, while the risk map illustrates the necessity to act in areas of high risk.
Acknowledgements The Swiss Federal Commission for Foreign Students and the Belgian Technical Cooperation financially supported this study. We thank the Directorial Board of the Research Institute of Geology and Mineral Resources (RIGMR) for logistic support. We thank Prof. Duong Duc Kiem and other researchers at the RIGMR for useful discussions, and Dang My Cung for his assistance in the field; a special thanks to the local people and army division for the sampling. We are gratefully to Prof. Daniel Hunkeler, Dr. Raymond Flynn, Prof. François Zwahlen and other researchers at the CHYN for fruitful discussions and useful advices. We thank Marie-Eve Wyniger for her help in the laboratory. We thank Dr. Okke Batelaan, Prof. Florimond De Smedt (Free University of Brussels) and other members of the VIBEKAP project for their friendly support, and David Drew (Trinity College, Dublin) for the final language check.

\section{References}

Aley T (1975) A predictive hydrogeological model for evaluating the effects of land use on the quantity and quality of water from Ozark Springs. Ozark Underground Laboratory, Missouri

Auckenthaler A, Huggenberger P (eds) (2003) Pathogene Mikroorganismen im Grund- und Trinkwasser [Pathogenic microorganisms in groundwater and drinking water]. Birkhäuser, Basel, pp 184

Auckenthaler A, Raso G, Huggenberger P (2002) Particle transport in a karst aquifer: natural and artificial tracer experiments with bacteria, bacteriophages and microspheres. Water Sci Technol 46(3):131-138

Bakalowicz M (2005) Karst groundwater: a challenge for new resources. Hydrogeol J 13(1):148-160

Boyer DG, Pasquarell GC (1999) Agricultural land use impacts on bacterial water quality in a karst groundwater aquifer. J Am Water Resour Assoc 35(2):291-300

BVSE (2002) Belgian-Vietnamese speleological expedition 2002: report of the sixth expedition in the province of Lai Chau. Belgian Vietnamese Karst and Caves Association, Caving Club of the University of Leuven (Belgium) and Research Institute of Geology and Mineral Resources Hanoi

Chapell FH (2001) Groundwater microbiology and geochemistry. Wiley, Chichester, NY

Currens JC (2002) Changes in groundwater quality in a conduitflow-dominated karst aquifer, following BMP implementation. Environ Geol 42(5):525-531

Dean JA (1995) Analytical chemistry handbook. McGraw-Hill, pp 1168

Drever JI (ed) (1997) The Geochemistry of natural waters: surface and groundwater environments. Prentice Hall, Englewood Cliffs, NJ, pp 436

Drew D, Hötzl H (eds) (1999) Karst hydrogeology and human activities: impacts, consequences and implications. Int Contrib Hydrogeol 20:151-159

Dreybrodt W (2000) Equilibrium chemistry of karst waters in limestone terranes. In: Klimchouk A, Ford DC, Palmer AN, Dreybrodt W (eds) Speleogenesis, evolution of karst aquifers. National Speleological Society, Inc., Huntsville, Alabama, USA, pp 126-135 
Dusar M, Masschelein J, Tien PC, Tuyet D (1994) Belgian-Vietnamese Speleological Expedition Son La 1993. Prof. Paper Belgian Geol. Surv. 1994/4-N.271, Belgian Geological Survey, Brussels

Dussart-Baptista L, Massei N, Dupont JP, Jouenne T (2003) Transfer of bacteria-contaminated particles in a karst aquifer: evolution of contaminated materials from a sinkhole to a spring. J Hydrol 284(1-4):285-295

Ford DC, Williams PW (1989) Karst geomorphology and hydrology. Chapman and Hall, London

Goldscheider N (2005a) Fold structure and underground drainage pattern in the alpine karst system Hochifen-Gottesacker. Eclogae Geol Helv 98:1-17

Goldscheider N (2005b) Karst groundwater vulnerability mapping: application of a new method in the Swabian Alb, Germany. Hydrogeol J 13:555-564

Goldscheider N, Hunkeler D, Rossi P (2006) Review: microbial biocenoses in pristine aquifers and an assessment of investigative methods. Hydrogeol J (in press). DOI 10.1007/s10040-0050009-9

Hung LQ, Dinh NQ, Batelaan O, Tam VT, Lagrou D (2002) Remote sensing and GIS- based analysis of cave development in the Suoimuoi Catchment (Son La, NW Vietnam). J Cave Karst Stud 64(1):23-33

Hurst CJ, Crawford RL, Knudsen GR, McInerney MJ, Stetzenbach LD (2002) Manual of environmental microbiology, 2nd edn. ASM, Washington, DC, $1158 \mathrm{pp}$

Japanese Mining Project (2002) Ore mining and environmental impact in Dong Pao area. Vietnamese Geological Survey, Hanoi

Käss W (1998) Tracing technique in geohydrology. Balkema, Rotterdam

Liu YB, Batelaan O, Huong NT, Tam VT, De Smedt F (2004) Flood prediction in the karstic Suoimuoi catchment, Vietnam. International Transdisciplinary Conference on Development and Conservation of Karst Regions, 13-18 September 2004, Hanoi, pp 139-144

Mahler BJ, Personne JC, Lods GF, Drogue C (2000) Transport of free and particulate-associated bacteria in karst. J Hydrol 238(3-4): 179-193

Mouret C (2004) Asia, southeast. In: J Gunn (ed) Encyclopedia of caves and karst sciences. Dearborn, New York, pp 100-104

My BP (1978) Geological map of Vietnam 1:200.000, Lao Cai-Kim Binh. Geological Survey of Vietnam, Hanoi

Nguyet VTM, Batelaan O, De Smedt F (2004a) Contribution to the karst hydrogeology of Son La, Vietnam by artificial tracer experiments. International Transdisciplinary Conference on Development and Conservation of Karst Regions, 13-18 September 2004, Hanoi, pp 160-164

Nguyet VTM, Goldscheider N, Batelaan O (2004b) Adaptation and application of the pan-European approach to groundwater vulnerability mapping to the Son La karst area, Vietnam. International Transdisciplinary Conference on Development and Conservation of Karst Regions, 13-18 September 2004, Hanoi, pp 165-168

Nguyet VTM, Goldscheider N (in press) A simplified methodology for mapping groundwater vulnerability and contamination risk, and its first application in a tropical karst area, Vietnam. Hydrogeol J (accepted for publication)

OXFAM-DELAGUA (2004) Water Testing Kit, Users Manual, Version 4.1, Robbens, Surrey, UK, pp 58

Panno SV, Hackley KC, Hwang HH, Kelly WR (2001) Determination of the sources of nitrate contamination in karst springs using isotopic and chemical indicators. Chem Geol 179(1-4): $113-128$
Pasquarell GC, Boyer DG (1995) Agricultural impacts on bacterial water-quality in karst groundwater. J Environ Qual 24(5):959-969

Payment P, Waite M, Dufour A (2003) Introducing parameters for the assessment of drinking water quality. In: Assessing microbial safety of drinking water: Improving approaches and methods. WHO Drinking Water Quality Series, IWA, London, pp 47-77

Pronk M, Goldscheider N, Zopfi J (2006) Dynamics and interaction of organic carbon, turbidity and bacteria in a karst aquifer system. Hydrogeol J 14:473-484

Ryan M, Meiman J (1996) An examination of short-term variations in water quality at a karst spring in Kentucky. Ground Water 34 (1):23-30

Saxena VK, Ahmed S (2003) Inferring the chemical parameters for the dissolution of fluoride in groundwater. Environ Geol 43 (6):731-736

Scanlon BR (1990) Relationships between groundwater contamination and major-ion chemistry in a karst aquifer. J Hydrol 119(1-4): 271-291

Smets BF, Siciliano SD, Verstraete W (2002) Natural attenuation: extant microbial activity forever and ever? Environ Microbiol 4 (6):315-317

Tam VT, Vu TMN, Batelaan O (2001) Hydrogeological characteristics of a karst mountainous catchment in the Northwest of Vietnam. Acta Geologica Sinica (English edn.). J Geol Soc China 75(3):260-268

Tam VT, De Smedt F, Batelaan O, Dassargues A (2004) Characterization of a cavernous conduit system by means of a time series correlation, cross-spectrum and wavelet analysis. Hydrol Sci J 49(5):879-900

Tam VT, De Smedt F, Batelaan O, Dassargues A (2005) Study on the relationship between lineaments and borehole specific capacity in a fractured and karstified limestone area in Vietnam. Hydrogeol J 13(5-6):675-689

Tapponier P, Peltzer G, Armijo R (1986) On the mechanics of the collision between India and Asia. In: Coward MP, Ries AC (eds) Collision tectonics. Geol Soc London Spec Publ 19:115-157

Thu T, Ban NV (1996) Geology and mineral deposits of the Phong Tho sheet. Intergeo, Hanoi

Tri TV, Tung NX, Uy ND (1977) Geology of Vietnam, the northern part. Hanoi Technical Science, Hanoi

Tuyet D (1998) Karst geology investigation of the northwest region. Research Institute of Geology and Mineral Resources, Hanoi, pp 251

Vaute L, Drogue C, Garrelly L, Ghelfenstein M (1997) Relations between the structure of storage and the transport of chemical compounds in karstic aquifers. J Hydrol 199(3-4):221-238

Veselic M (2003) Protection of groundwater in classical Karst systems. Crit Rev Anal Chem 33(4):327-332

Vesper DJ, Loop CM, White WB (2001) Contaminant transport in karst aquifers. Theoreti Appl Karstol 13-14:101-111

VIBEKAP (2003) Vietnamese-Belgian Karst Project: report on research results. Catholic University of Leuven-Research Institute of Geology and Mineral Resources, Leuven, Belgium, pp 298

WHO (2004) Guidelines for drinking-water quality, vol 1, Recommendations, 3rd edn. World Health Organisation, Geneva, pp 515

Young CP (1983) Topic-1: data acquisition and evaluation of groundwater pollution by nitrates, pesticides, and diseaseproducing bacteria. Environ Geol 5(1):11-18

Zwahlen F (ed) (2004) Vulnerability and risk mapping for the protection of carbonate (karst) aquifers, final report COST action 620. European Commission, Brussels 